\title{
EVOLUTIONARY PROTOTYPE DALAM PERANCANGAN SISTEM INFORMASI GUNA MENINGKATKAN PENJUALAN
}

\author{
Oky Irnawati ${ }^{1 *}$, Ida Darwati ${ }^{2}$ \\ Program Studi Teknik Elektro, Universitas Bina Sarana Informatika, Jakarta ${ }^{1}$ \\ Sistem Informasi, Universitas Bina Sarana Informatika, Jakarta ${ }^{2}$ \\ e-mail: oky.okt@bsi.ac.id ${ }^{1}$,ida.idd@bsi.ac.id ${ }^{2}$
}

\begin{abstract}
Abstrak
Wawan toys merupakan toko yang menjual aneka mainan dengan spesifikasi mobil-mobilan modifikasi yang saat ini belum memiliki web e-commerce sebagai media promosi serta penunjang transaksi penjualannya. Tidak dapat dipungkiri bahwa e-commerce banyak memberikan manfaat dalam hal pemasaran suatu produk yang tidak mengenal jarak dan waktu. Oleh sebab itu penulis tertarik untuk membuat rancangan sistem informasi bagi Wawan toys, menggunakan teknik pengembangan Evolutionary Prototype yaitu penulis membuat prototype hingga sesuai dengan sistem yang dibutuhkan oleh pengguna dalam upaya meningkatkan penjualan. Penulis menggambarkan rancangan dimulai dari menggambarkan use case diagram, activity diagram, class model sebagai rancangan untuk pembuatan database. Dari hasil penelitian penulis menyimpulkan bahwa perancangan sistem informasi penjualan ini memberi kemudahan bagi pemilik Wawan toys serta pembelinya dalam melakukan transaksi.
\end{abstract}

Kata kunci : Evolutionary Prototype; Penjualan, Perancangan Sistem Informasi

\begin{abstract}
Wawan toys is a store that sells a variety of toys with specifications of modified cars that do not currently have web e-commerce as a promotional media and support sales transactions. There is no denying that e-commerce provides many benefits in terms of marketing a product that does not recognize distance and time. Therefore, the author is interested in designing an information system for Wawan toys, using evolutionary prototype development techniques that is the author makes prototypes to fit the system needed by users in an effort to increase sales. The author describes the design starting from describing the use case diagram, activity diagram, class model as the design for database creation. From the results of the study the author concluded that the design of this sales information system provides convenience for the owner of Wawan toys and its buyers in making transactions.
\end{abstract}

Keywords : Evolutionary Prototype; Sales, Information System Design

\section{PENDAHULUAN}

Ecommerce telah menjadi gaya hidup saat ini. Ecommerce memberikan kemudahan bertransaksi yang dapat dilakukan secara online dimana pembeli tidak perlu datang ke toko untuk membeli suatu barang [1]. Banyak cara menjual barang secara online diantaranya lewat perantara ecommerce atau marketplace atau bisa juga melalui media sosial. Banyak keuntungan yang bisa didapat dari marketplace diantaranya mudahnya proses membuka toko, sering kali marketplace memberikan subsidi berupa gratis ongkos kirim dan cashback, telah terpercaya oleh pembeli. Kekurangan membuka toko di marketplace diantaranya pemilik toko tidak leluasa dalam mengatur produk, adanya perang harga yang dapat mematikan persaingan dan sulit membangun brand 
karena ada dibawah nama marketplace. Sedangkan menggunakan media social pembeli biasanya kurang percaya dan terbatas pada relasi penjual [2]. Memiliki website sendiri untuk toko online diharapkan dapat menambah kepercayaan pembeli, memberikan keleluasaan pada penjual untuk mengelola produk melalui tampilan website dan fitur yang dapat diatur sendiri dan terutama dapat membangun brand. Pengembangan system informasi pada penelitian-penelitian terdahulu umumnya menggunakan metode waterfall, dengan waterfall maka system yang dibangun relative lebih lama karena pengerjaan tahapan dilakukan satu per satu, sedangkan dengan pengembangan system informasi menggunakan metode evolutionary prototype, system dapat dibangun dengan waktu relative lebih cepat karena pengembangan system informasi berdasarkan prototype yang diberikan kepada user dan diperbaiki secara bertahap sampai sesuai dengan kebutuhan user tersebut.

\section{TINJAUAN PUSTAKA}

\subsection{Sistem Informasi}

Menurut Bonnie Soeherman dan Marion Pinontoan definisi "Sistem informasi merupakan serangkaian komponen berupa manusia, prosedur, data dan teknologi (seperti komputer) yang digunakan untuk melakukan sebuah proses untuk menghasilkan informasi yang bernilai untuk pengambilan keputusan". Sedangkan definisi web menurut Eko Priyo Utomo dan Syafrudin "web atau WWW adalah dokumen atau informasi yang saling berhubungan yang dihubungkan melalui hyperlink atau URL (Uniform Resource Locator)" [3].

Pengertian diatas memberikan gambaran mengenai sistem informasi berbasis web yang dapat dimaknai sebagai serangkaian prosedur yang menghasilkan informasi bernilai melibatkan manusia, data, teknologi dihubungkan melalui URL.

\section{$2.2 \quad$ UML}

"UML merupakan bahasa visual untuk pemodelan dan komunikasi mengenai sebuah sistem dengan menggunakan diagram dan teks-teks pendukung" [4].

Pada penelitian ini rancangan sistem dibuat dengan UML yakni dengan menggambarkan interaksi antara sistem dengan user yang terlibat menggunakan diagram use case. Penggambaran tahapantahapan yang dikerjakan sistem dan user yang terlibat dengan menggunakan activity diagram serta perancangan database sebagai pengelola data beserta tabel-tabel, atribut dan relasinya digambarkan dengan class model.

\subsection{Penelitian Terdahulu}

Beberapa penelitian terdahulu yang menjadi referensi penelitian ini diantaranya:

Penelitian Yessi Hartiwi dengan judul "Analisis Dan Implementasi Sistem Informasi Penjualan Berbasis Web Pada Scarlet Butik" membuat rancangan sistem penjualan berbasis web menggunakan tools use case diagram, activity diagram dan class diagram sehingga menghasilkan sistem penjualan yang lebih menarik dan memudahkan pengguna dalam bertransaksi di Scarlet butik [5].

Penelitian M. Agung Setiabudi dan Andi Iwan Nurhidayat dengan judul "Aplikasi Sistem Informasi Penjualan Motor Custom Berbasis Website Menggunakan Framework Codeigniter" memberikan kesimpulan pembuatan aplikasi penjualan motor memiliki kelebihan dengan memberikan tampilan sederhana namun mudah dipahami dalam proses penjualan serta penggunaan database yang memiliki daya tampung cukup besar untuk penyimpanan data transaksi penjualan [6]. 
Penelitian Syaiful Anwar dengan judul "Rancangan Aplikasi Penjualan Perlengkapan Dan Mainan Anak Menggunakan Konsep Model View Controller (MVC)" mengungkapkan system informasi atau aplikasi penjualan perlengkapan dan mainan anak PT. Harmoni Lintas Gaya memberikan pemecahan permasalahan dalam memperluas jangkauan pemasaran, peningkatan nilai jual serta menjadi solusi yang memudahkan user dalam bertransaksi penjualan perlengkapan dan mainan anak [7].

Penelitian Triana Fatmawati dan Imam Adi Praja yang berjudul "Analisis dan Perancangan Sistem Informasi Penerimaan Bahan Baku Bearing Pada PT SKF Indonesia" menggunakan evolutionary prototyping sebagai model dalam mengembangkan sistem informasi [8].

Beberapa penelitian terdahulu menjadi dasar untuk pengembangan dan perbaikan pada penelitian ini. Umumnya sistem informasi dibangun dengan menggunakan metode waterfall, namun melihat dari kekurangan metode waterfall yakni biaya dan waktu yang relatif lebih mahal dan lebih lama, maka penelitian ini mengusulkan untuk membangun sistem informasi menggunakan metode evolutionary prototype dengan biaya yang lebih murah dan waktu yang lebih cepat.

\section{METODOLOGI PENELITIAN}

Penulis menggunakan metode Evolutionary prototype dalam penelitian ini. Dalam buku Mulyani menurut Raymond McLeod, Jr. dan George P. Schell, "Evolutionary prototype yaitu, prototype yang secara terus menerus dikembangkan hingga prototype tersebut memenuhi fungsi dan prosedur yang dibutuhkan oleh sistem. Berikut gambar dari tahapan evolutionary prototype:" [9]

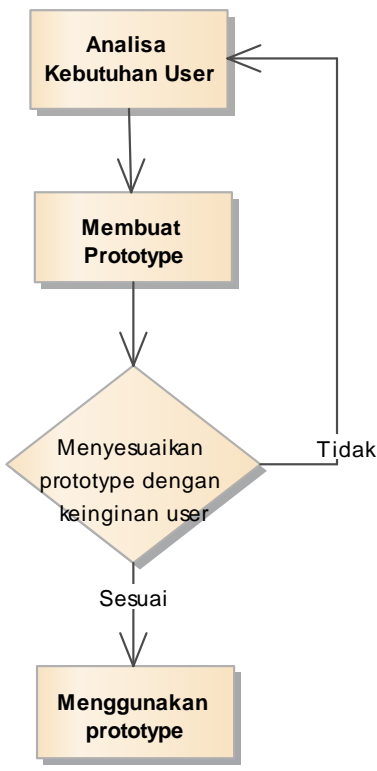

Gambar 1 Tahapan Evolutionary Prototype Sumber : [9]

Penerapan metode Evolutionary prototype pada penelitian ini sebagai berikut:

1. Analisis kebutuhan user

Pada tahap ini dilakukan penelitian terhadap kebutuhan user sebagai tahap awal dalam merancang sistem informasi yang tepat.

2. Membuat prototype

Pembuatan rancangan sistem penjualan dimulai dengan rancangan sistem menggunakan UML yang digambarkan melalui use case diagram dan activity diagram, rancangan database menggunakan class model dan rancangan interface berbasis website.

3. Menyesuaikan prototype dengan keinginan user, rancangan disesuaikan dengan kebutuhan pengguna sebagai pengelola yaitu dapat mengelola data barang dan tampilan website secara keseluruhan. Rancangan kebutuhan sebagai pengguna yaitu dapat melakukan pembelian barang dan konfirmasi pembayaran.

4. Menggunakan prototype, pemilik toko dapat menggunakan usulan prototype yang penulis rancang sebagai acuan untuk menjalankan system informasi penjualan berbasis website. 


\section{HASIL DAN PEMBAHASAN}

\subsection{Analisis Kebutuhan User}

Berdasarkan analisa penulis mengenai sistem penjualan di toko Wawan Toys yang masih dilakukan secara konvensional, menyebabkan kurangnya promosi, sehingga produk tidak dapat dipasarkan secara luas. Penjualan konvensional juga mengharuskan pembeli datang langsung, yang menjadikan tidak efektifnya proses pembelian produk. Melihat hal ini, maka penulis membuat sistem informasi penjualan secara terkomputerisasi yang dapat diakses melalui jaringan online.
Sesuai kebutuhan maka user dalam sistem informasi penjualan dibagi menjadi dua. User sebagai pengelola website dan user sebagai pengguna website. Pengelola website adalah pihak yang menjual barang, user ini membutuhkan akses untuk pengelolaan data barang, melakukan konfirmasi pengiriman barang serta mengelola website secara keseluruhan, sedangkan sebagai pengguna website, user membutuhkan akses untuk melihat barang, melakukan pembelian barang dan melakukan konfirmasi pembayaran.

\subsection{Membuat Prototype}

Pada tahapan ini, penulis menggambarkan use case diagram, activity diagram dan class model.

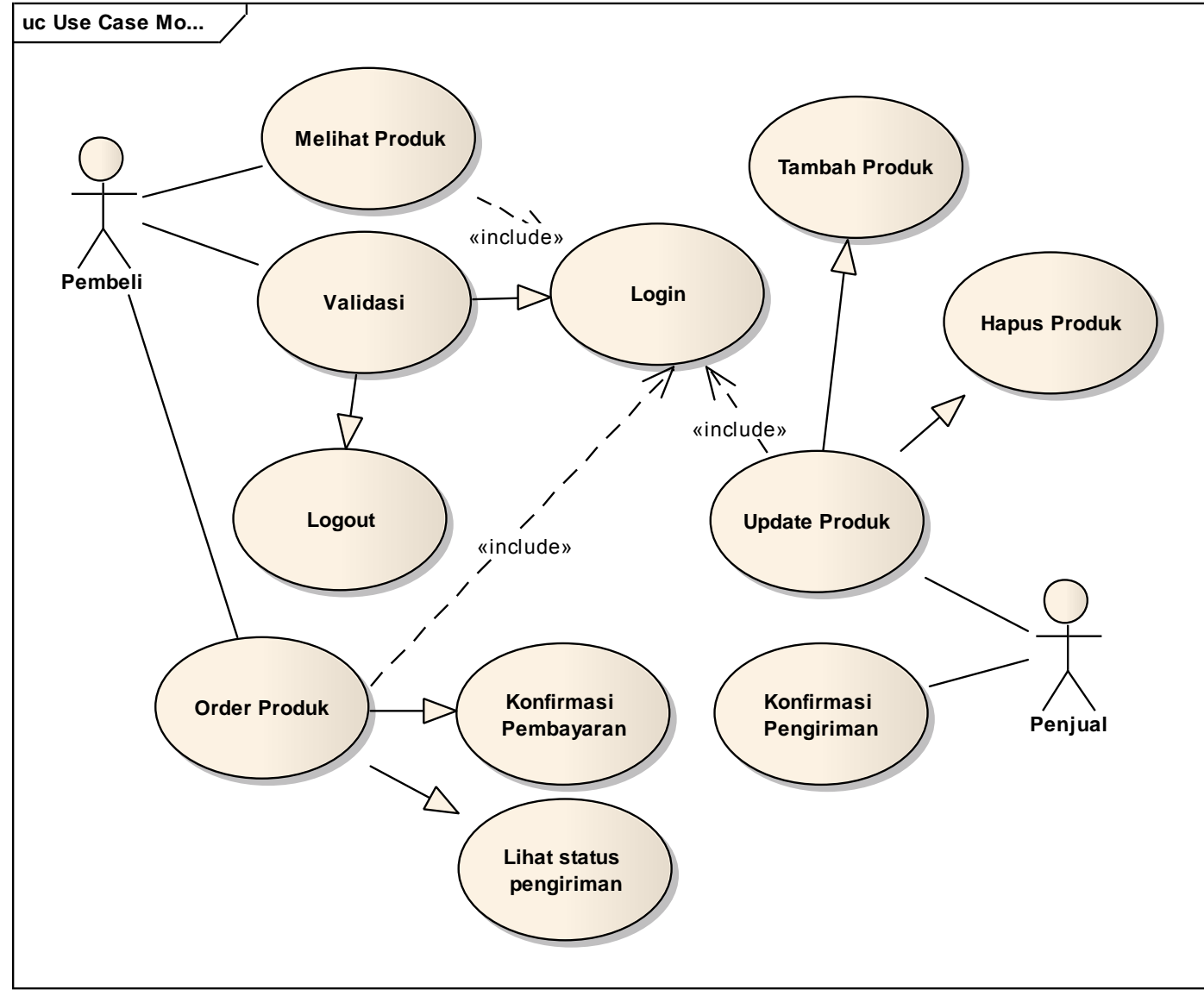

Gambar 2 Use Case Diagram Sistem Informasi Penjualan Wawan Toys Sumber : Hasil Penelitian 
Berdasarkan gambar use case diatas dapat dilihat user yang terlibat dalam sistem informasi penjualan ada dua yaitu pembeli dan penjual. Pembeli harus terlebih dahulu login kemudian data akan divalidasi, kemudian pembeli dapat mengakses halaman untuk melihat produk dan melakukan order produk. Setelah melakukan order produk, pembeli membayar dengan cara transfer dan melakukan konfirmasi melalui halaman konfirmasi pembayaran. Tahap terakhir pembeli dapat melihat status pengiriman produk.

Sedangkan dari sisi penjual, terlebih dahulu harus melakukan login. Penjual dapat menambah produk, hapus produk, update produk dan melakukan konfirmasi pengiriman berdasarkan data pesanan dari sisi pembeli.

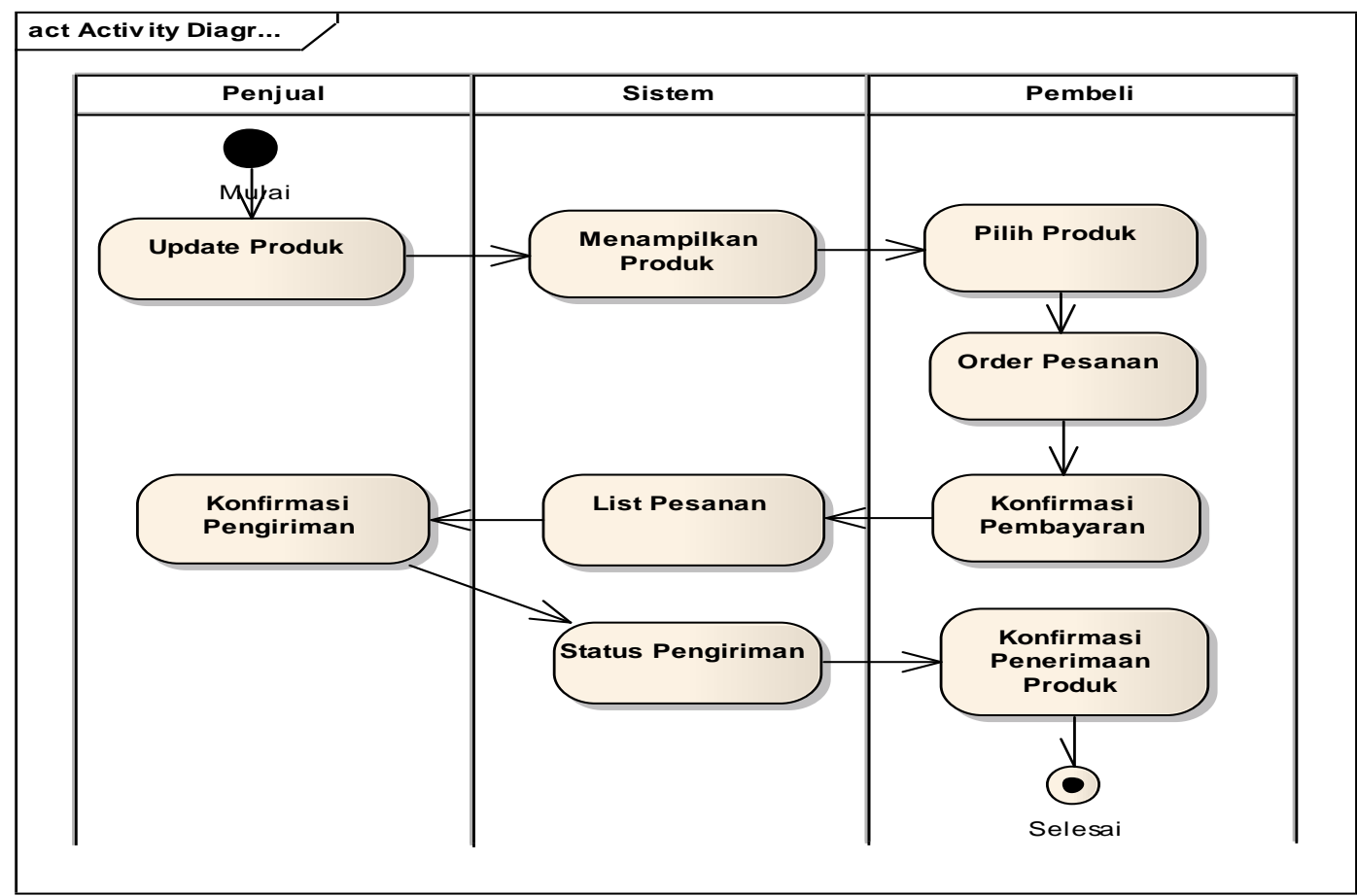

Gambar 3 Activity Diagram Sistem Informasi Penjualan Wawan Toys Sumber : Hasil Penelitian 


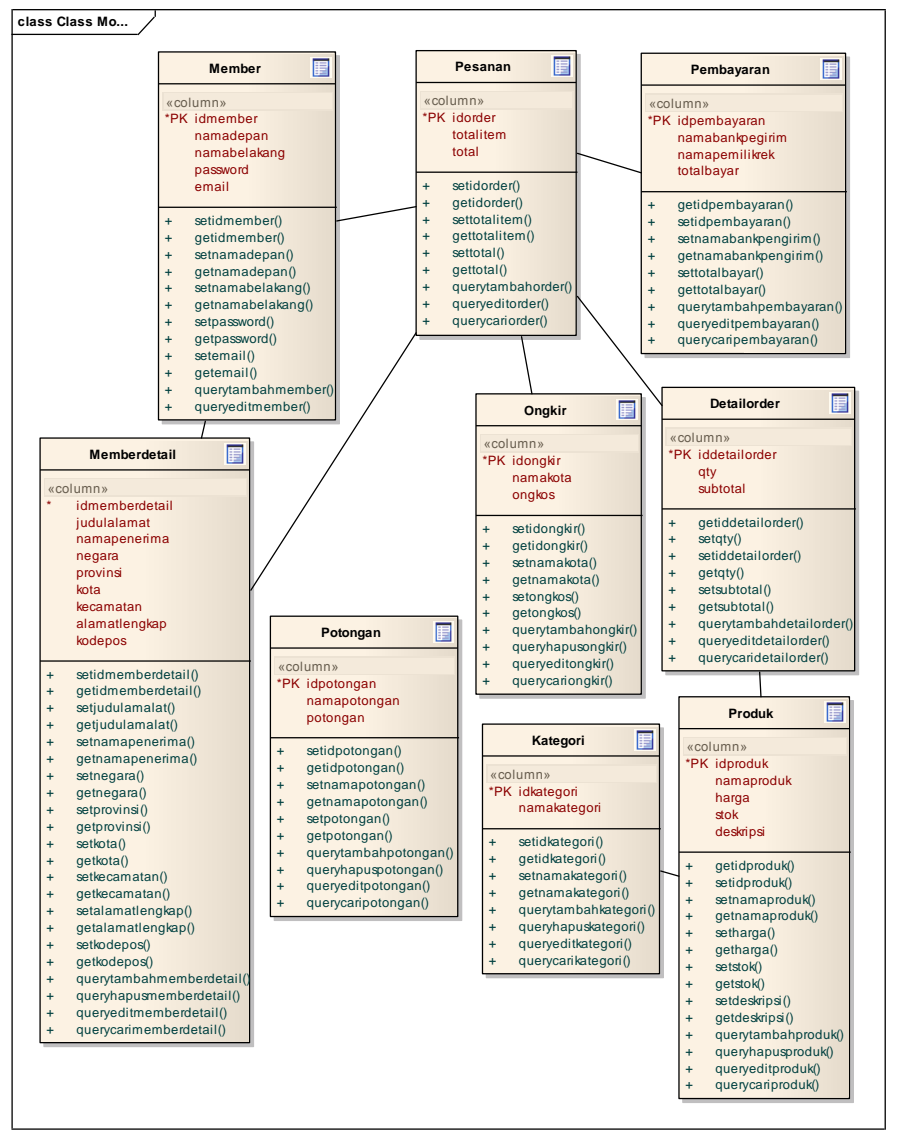

Gambar 4 Class Model Sistem Informasi Penjualan Wawan Toys Sumber : Hasil Penelitian

\subsection{Menyesuaikan Prototype dengan Keinginan User}

Berikut ini rancangan yang disesuaikan dengan kebutuhan pengguna.

A. Tampilan Home

Pada halaman ini, user dapat melihat produk yang terdiri dari nama produk, deskripsi dan harga, user dapat langsung mengklik gambar jika ingin memasukan produk ke keranjang belanja. Pada halaman home terdapat menu registrasi untuk user yang belum terdaftar dan menu login untuk user yang telah mendaftar sebelumnya. Terdapat pula menu pencarian untuk melakukan pencarian produk.

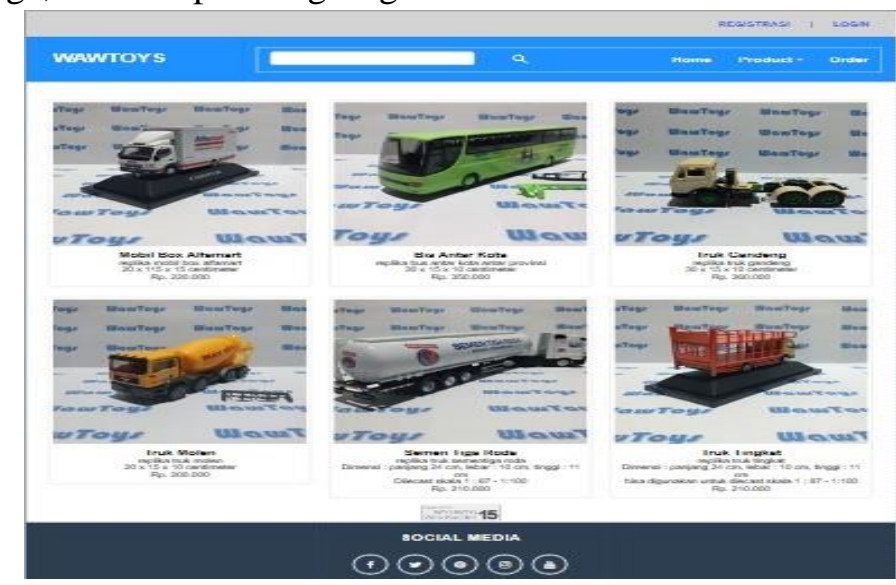

Gambar 5 Rancangan Tampilan Home

Sumber : Hasil Penelitian 
B. Tampilan Keranjang Belanja

Pada halaman keranjang belanja, user dapat melihat produk yang telah dipilih sebelumnya. Terdapat keterangan produk, harga, jumlah beli produk, total harga yang merupakan hasil dari jumlah beli dikalikan harga produk. User juga diberikan tombol hapus untuk menghapus masing-masing produk dari keranjang belanja. Terdapat alamat pengiriman yang dapat diubah jika alamat yang tertera bukan alamat pengiriman. User dapat mengklaim voucher untuk potongan harga. Terakhir user dapat melihat harga yang harus ditransfer dan melakukan checkout jika semua yang tertera sudah sesuai pesanan.

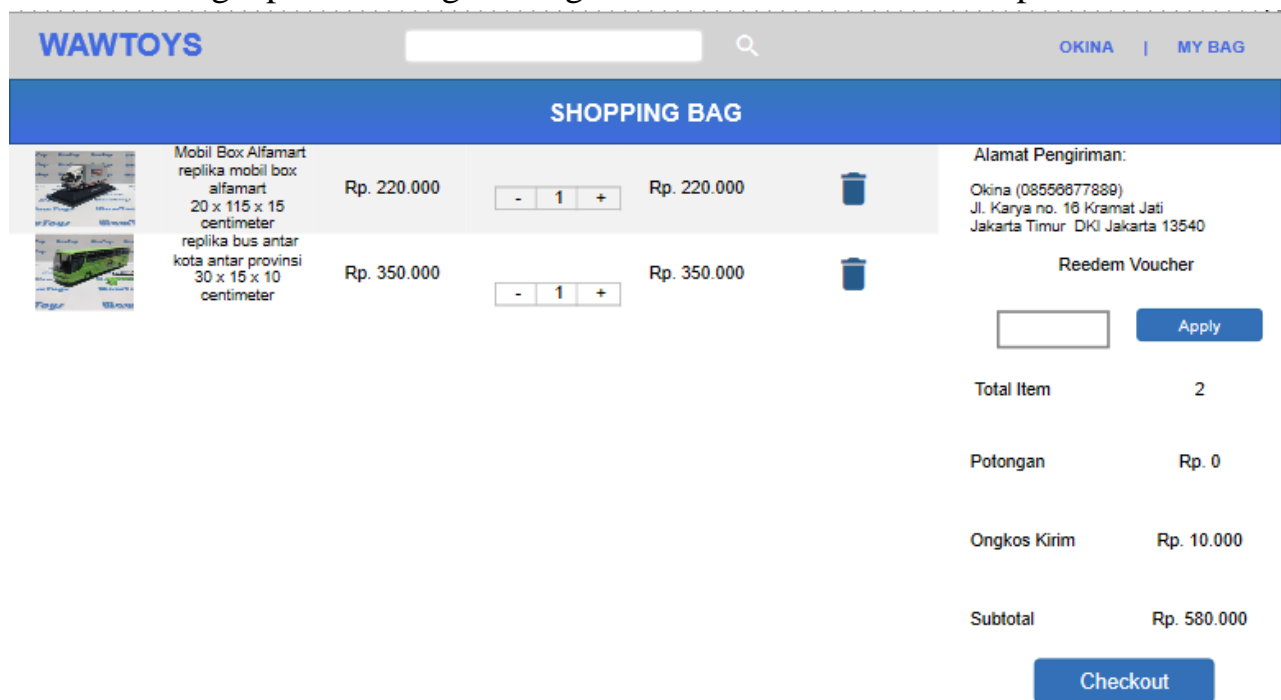

Gambar 6. Rancangan Tampilan Keranjang Belanja

Sumber : Hasil Penelitian

C. Tampilan Konfirmasi Pembayaran

Pada halaman konfirmasi

pembayaran, user disajikan beberapa pilihan metode pembayaran. Setiap menunya berisi panduan cara mentransfer pembayaran atas produk yang sebelumnya telah dipesan. Setelah melakukan pembayaran sesuai metode pembayaran yang dipilih, user dapat melakukan konfirmasi. System akan meneruskan konfirmasi pembayaran ini kepada penjual untuk kemudian penjual melakukan pengecekan pembayaran dan melakukan pengiriman barang.

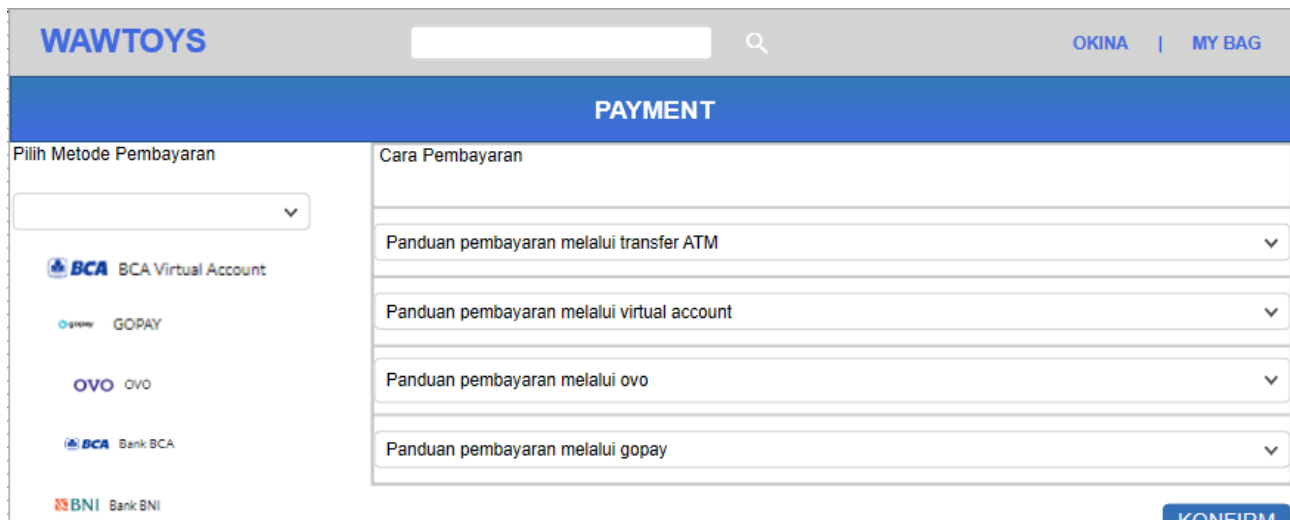

Gambar 7. Rancangan Tampilan Konfirmasi Pembayaran

Sumber : Hasil Penelitian 


\subsection{Menggunakan Prototype}

Prototype selanjutnya dapat dikembangkan untuk menjalankan sistem penjualan mainan pada toko Wawantoys.

\section{KESIMPULAN}

Dari penelitian ini, penulis membuat kesimpulan bahwa:

1. Dengan rancangan sistem informasi hasil dari penelitian dapat membantu pemasaran barang serta memudahkan dalam melakukan transaksi penjualan.

2. Pembeli dapat dengan mudah mengetahui adanya barang dengan model terbaru dan melakukan transaksi dari mana saja dan kapan saja.

3. Pemilik toko dapat lebih mudah memonitoring semua transaksi penjualan yang terjadi, dari mulai pemesanan, konfirmasi pembayaran sampai dengan diterimanya barang oleh pembeli.

\section{SARAN}

Demi kelancaran, keamanan serta kenyamanan dalam bertransaksi, penulis menyarankan hasil dari penelitian ini dapat dikembangkan lebih lanjut.

\section{DAFTAR PUSTAKA}

[1] H. Purwanto, A. Sumbaryadi, and M. Informatika, "E-CRM Berbasis Web Pada Sistem Informasi Penjualan Funiture," vol. 14, no. 1, pp. 15-20, 2018.

[2] N. A. Safitri, "Strategi Komunikasi Pemasaran Untuk Meningkatkan
Daya Beli Konsumen Melalui Media Sosial," Kompetensi, vol. 11, no. 2, pp. 210-216, 2011.

[3] A. Prasetyo and R. Susanti, "Sistem Informasi Penjualan Berbasis Web Pada PT. Cahaya Sejahtera Sentosa Blitar," J. Ilm. Teknol. Inf. Asia, vol. 10, no. 2, pp. 1-16, 2016.

[4] R. A. Sukamto and M. Shalahuddin, Rekayasa Perangkat Lunak (Terstruktur dan Berorientasi Objek). Bandung: Informatika Bandung, 2016.

[5] Y. Hartiwi, "Analisis Dan Implementasi Sistem Informasi Penjualan Berbasis Web Pada Scarlet Butik | Jurnal Ilmiah Media Sisfo," JURNAL ILMIAH MEDIA SISFO, 2017. [Online]. Available: http://ejournal.stikom-

db.ac.id/index.php/mediasisfo/article /view/215. [Accessed: 04-Jun-2020].

[6] M. A. Setiabudi and A. I. Nurhidayat, "Aplikasi Sistem Informasi Penjualan Motor Custom Berbasis Website Menggunakan Framework Codeigniter," J. Manaj. Inf., vol. 9, no. 2, pp. 69-78, 2019.

[7] S. Anwar et al., "Rancangan Aplikasi Penjualan Perlengkapan Dan Mainan Anak Menggunakan Konsep Model View," vol. 2, no. 1, 2020.

[8] T. Fatmawati and I. A. Praja, "Analisis Dan Perancangan Sistem Informasi Penerimaan Bahan Baku Bearing Pada PT SKF Indonesia," $J$. Teknol. dan Manaj., vol. 16, no. 2, pp. 138-151, 2018.

[9] S. Mulyani, Metode Analisis dan Perancangan Sistem. Bandung: ABDI SISTEMATIKA, 2016. 